DOI https://doi.org/10.36059/978-966-397-240-4-25

\author{
Воленщук Н. А. \\ кандидат економічних наук, \\ заступник директора з наукової роботи \\ Донецька державна сільськогосподарська дослідна станція \\ Національної академії аграрних наук України \\ м. Покровськ, Донецька область

\section{ІННОВАЦІЙНА ДІЯЛЬНІСТЬ НАУКОВИХ УСТАНОВ АГРАРНОЇ СФЕРИ: РЕАЛІЇ ТА НАПРЯМИ АКТИВІЗАЦІЇ}

Анотація. В статті висвітлено концептуальні засади та основні результати наукових досліджень із питань інноваційного розвитку та трансферу технологій науково-дослідних установ аграрної сфери. Досліджено та надано оцінку стану інноваційної діяльності наукових установ сектору АПК. У статті розглянуто проблеми розвитку інноваційної діяльності вітчизняних наукових установ та основні перепони, які стоять перед сільськогосподарськими підприємствами на етапі впровадження інновацій. Розглянуто динаміку подачі заявок на об'єкти інтелектуальної власності та отримання охоронних документів установами Національної академії аграрних наук України. Систематизовано та наведено інформацію щодо впровадження затребуваних наукових розробок у діяльність сільськогосподарських підприємств, визначено їх економічну ефективність. Окреслено методи популяризації наукоємної продукції на ринку, які здійснювались науковими установами. Обгрунтовано організаційно-економічні напрями активізації інноваційної діяльності в стратегічному розвитку сільськогосподарських підприємствах. Проаналізовано результати комерціалізації наукоємної продукції та надані практичні рекомендації, які здатні посилити роль дослідних установ у сфері наукового забезпечення.

\title{
Вступ
}

Основним завданням економічної політики України є подальший розвиток інноваційної моделі національної економіки з метою прискорення темпів зростання, досягнення стабільної конкурентоспроможності на світовому ринку шляхом здійснення експорту високотехнологічної продукції та збільшення ії частки, поступове 
забезпечення необхідних темпів імпортозаміщення, раціонального використання всіх ресурсів. Активізація інноваційної діяльності наукових установ аграрної сфери зумовлена посиленням конкурентної боротьби на ринку сільськогосподарської продукції та інтеграцією України в міжнародний економічний простір. Дослідження показали, що інноваційні складові наукового процесу ще не повністю освоєні науково-дослідними установами та потребують роз'яснення питання щодо реєстрації прав на завершені наукові розробки, механізму їх ефективної комерціалізації, оцінки ОПІВ та правової охорони, налагодження системи економічних відносин між учасниками інноваційного процесу 3 метою стимулювання впровадження інновацій у виробництво.

Повільні темпи впровадження інновацій пов'язані, в першу чергу, з низькою платоспроможністю сільськогосподарських підприємств, а також із недостатньою проінформованістю та обізнаністю управлінців підприємств про досягнення аграрної науки. У зв'язку з чим нагальним питанням для наукових установ аграрної сфери $\epsilon$ створення дієвого механізму з відповідними інструментами щодо перетворення завершених розробок у наукоємну продукцію, пошук шляхів комерційного впровадження інновацій та ознайомлення керівників сільськогосподарських підприємств із сучасними технологіями та селекційними здобутками з метою їх впровадження та ефективного використання у діяльності суб'єктів господарювання.

Одними із найважливіших завдань агропромислового комплексу на сьогодні $є$ досягнення стійкого розвитку сільського господарства та збільшення обсягів виробництва сільськогосподарської продукції. Для того, щоб наповнити реальним змістом новий статус сільськогосподарського виробника, необхідно привести у відповідність із вимогами ринкових відносин організаційно-економічний механізм інноваційного забезпечення аграрного виробництва, тобто систему відповідних форм і методів впливу на виробництво для досягнення поставлених цілей $[1 ; 3 ; 4 ; 6 ; 16 ; 17 ; 20]$.

Інноваційна діяльність включає в себе весь інноваційний процес - від виникнення нових ідей та знань до розповсюдження наукового продукту в практичній діяльності. Інноваційна модель розвитку агропромислового комплексу передбачає використання нових прогресивних технологій або їі елементів, високопродуктивних сортів сільськогосподарських культур, нових порід і типів худоби, ветеринарних препаратів [4; 20]. Важливою умовою розвитку та підвищення ефективності функціонування агропро- 
мислового комплексу є посилення інтеграції науки з виробництвом, широке впровадження наукових досягнень у практику роботи аграрних підприємств і організацій.

Сучасні умови ринкового середовища вимагають від керівників сільськогосподарських підприємств якісно нових підходів до прийняття управлінських рішень. У сучасних умовах основним засобом зростання й розвитку сільськогосподарського виробництва в довгостроковій перспективі стають досягнення науково-технічного прогресу та інновації. На переконання науковців Національної академії аграрних наук України, забезпечення ефективного розвитку сільськогосподарського виробництва в ринкових умовах можливе за умов переходу галузі на інноваційну модель розвитку, нарощування обсягів інвестицій, побудови інтегрованої ринкової інфраструктури, що створює підгрунтя для функціонування науки та підприємництва в єдиному збалансованому комплексі [17, с. 92]. На сьогодні постійне впровадження новітніх розробок $\epsilon$ реальною запорукою сталого розвитку сільського господарства.

\section{1. Вплив інноваційної діяльності на розвиток потенціалу суб'єктів господарювання аграрної сфери}

Аналізуючи стан агропромислового комплексу, можемо відзначити, що інтенсифікацію його розвитку та стабілізацію обсягів виробництва сільськогосподарської продукції досягнуто за рахунок впровадження у виробництво елементів науково-обгрунтованої системи землеробства та ресурсозберігаючих технологій, використання сортів та гібридів сільськогосподарських культур, адаптованих до природно-кліматичних умов області, плідної співпраці «держави-науки-бізнесу», міжнародної фінансової підтримки фермерства, отримання державних дотацій.

Осередком створення інноваційної продукції $є$ науково-дослідні установи, дослідження яких спрямовані на розробку інноваційних технологій у рослинництві та тваринництві, створення сортів зернових і кормових культур, розроблення науково-організаційних підходів та ринково-орієнтованого інструментарію випробовування, експериментального виробництва та консалтингового супроводу трансферу інноваційних технологій у агропромисловому комплексі регіону. На рис. 1 показано принципову схему руху від інноваційної ідеї до реалізації інноваційної продукції на ринку.

Схема відображає трансформацію результатів наукових досліджень і розробок або інших науково-технічних досягнень у новий 
технологічний процес або у новий продукт, які впроваджуються в виробничий процес та забезпечують отримання економічних вигід від їхнього використання.

Як наголошує О.В. Гончаренко в своєму дослідженні, в інноваційній сфері національної економіки сформувались суттєві системні перешкоди на шляху здійснення інноваційної діяльності через обмежене фінансування, значні втрати кадрового науковоінноваційного потенціалу, недостатній розвиток патентної діяльності, неефективне державне управління інноваційною діяльністю, відсутність модернізаційних перетворень в економічному секторі, недостатню інтеграцію вітчизняних підприємств у світогосподарські процеси, низький рівень інноваційної культури та нерозвиненість інформаційної структури [6, с. 104].

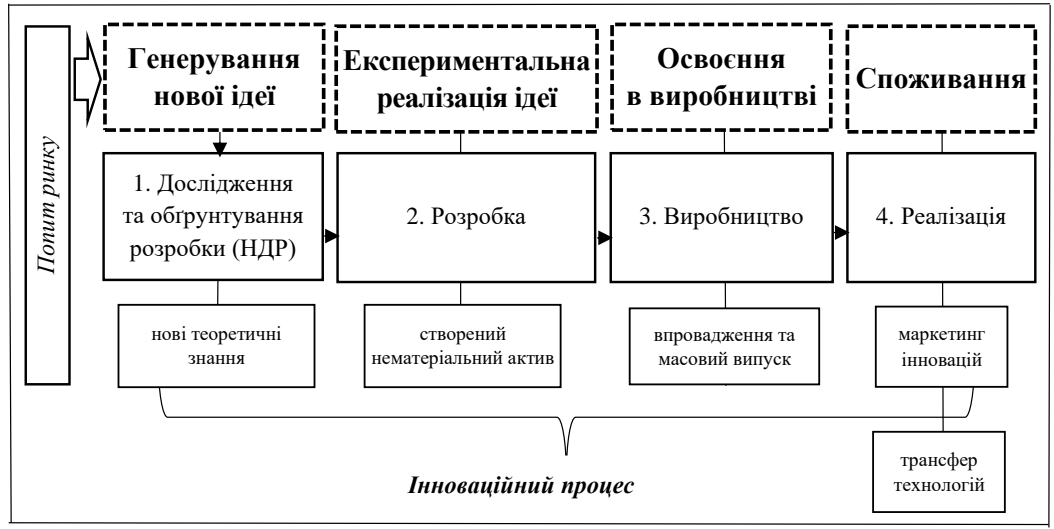

Рис. 1. Етапи трансформації наукової ідеї в інноваційний продукт

Джерело: розроблено автором

На думку В.Б. Смолінського, головною причиною низької інноваційної активності вітчизняних підприємств вважається відсутність економічних механізмів зацікавленості у впровадженні новацій у виробництво. Інноваційну діяльність підприємства проводять в основному самостійно через обмежені фінансові можливості для вирішення науково-технологічних проблем. Технічний рівень засвоєної вітчизняним виробництвом продукції знижується, впроваджуються в основному нововведення, які не потребують значних 
фінансових витрат. Як показує досвід, зарубіжні товари витіснили з внутрішнього ринку національну наукомістку продукцію, а через високі витрати на освоєння продукції сучасного технологічного рівня підприємства намагаються ігнорувати довготривалі наукомісткі проект [21, с. 288].

Упродовж 2018-2020 pp. частка підприємств, які займались інноваційною діяльністю, становила $18,2 \%$, у т. ч. здійснювали технологічні інновації - 9,6\%, нетехнологічні - 8,7 \%. Слід зазначити, що існує прямий зв'язок між розміром підприємства та його рівнем інноваційності, оскільки для впровадження інновацій необхідно мати певну кількість персоналу, задіяного у виконанні наукових досліджень і розробок. Відповідно, найвища частка як технологічно активних, так і нетехнологічно активних підприємств була серед великих підприємств (відповідно 32,9 \% і 20,7 \%) [11].

Інноваційний розвиток підприємств не можливо стимулювати і підтримувати без достатнього фінансового забезпечення. Відзначимо, що фінансування науково-дослідних робіт наукових установ України здійснюється за рахунок бюджетних асигнувань. На рис. 2 графічно наведена структура фінансування наукових досліджень та розробок в розрізі галузевих академій України та підпорядкованих їм установ. Якщо порівняти фінансування 2020 р. проти 2018 р., слід відзначити, що суттєвих змін, які б вплинули на зміну структури між галузевими академіями, не відбулося, але зміни торкнулися деяких академій. Наочно бачимо, що в 2020 році фінансування академії аграрних наук України збільшилось на $2 \%$, а фінансування академії медичних наук - на $1 \%$.

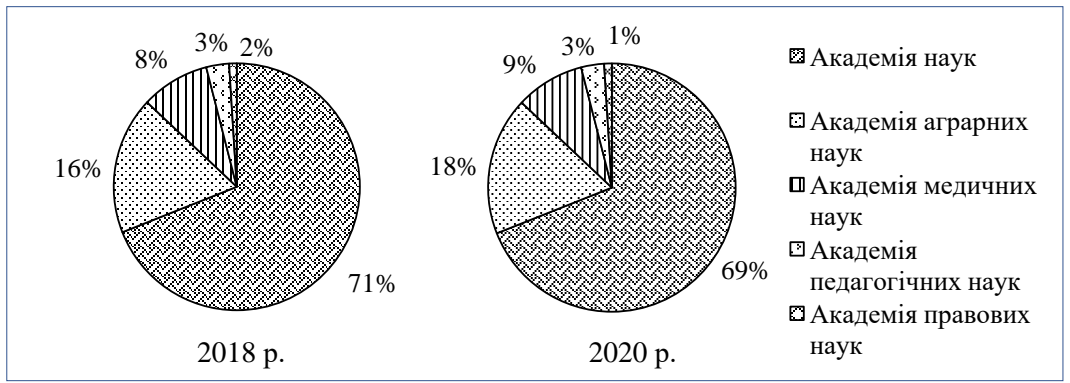

\section{Рис. 2. Фінансування наукових досліджень і розробок, 2018-2020 pp.}

Джерело: складено автором за [11] 
Для покращення стану інноваційного середовища на підприємствах, насамперед, потрібно усвідомити, що кількість інноваційно активних підприємств буде зменшуватись за відсутності підтримки держави, як законодавчо, так і в фінансовому плані [11].

Як свідчать дані Державної служби статистики України у 2020 р. витрати на інновації в основному здійснювались за рахунок власних коштів (понад $90 \%$ загального обсягу фінансування), кредитів $(3,5 \%)$ та бюджетних коштів $(2,8 \%)$. Обсяг реалізованої у 2020 р. інноваційної продукції склав 2,9 \% (у т.ч. нових для ринку 0,9\%, нових лише для підприємства - 2,0 \%) загального обсягу реалізованої продукції обстежених підприємств [11].

Проаналізувавши дані підприємств стосовно інноваційної діяльності в розрізі регіонів України, слід відмітити, що у 2020 р. найвищий рівень інноваційної активності спостерігався на підприємствах Рівненської, Івано-Франківської та Харківської областей. Найвища частка технологічно інноваційних підприємств у Харківській (16,9\%), Івано-Франківській $(16,6 \%)$ та Рівненській $(15,2 \%)$ областях [11].

Науково-дослідна робота $є$ невід'ємною складовою наукової діяльності установи. Наукові інститути, отримуючи бюджетні кошти на проведення науково-дослідних робіт, проводять теоретичні, прикладні дослідження та розробки у відповідній галузі, координують та здійснюють науково-методичне забезпечення наукових досліджень установ, які їм підпорядковані. Як вже зазначалось, ядром створення інноваційної продукції в агропромисловому комплексі $є$ науково-дослідні установи Національної академії аграрних наук України. Саме вони отримують бюджетні кошти на виконання науково-дослідних робіт та здійснюють впровадження наукових розробок у виробництво. Основним продуктом, що виробляють наукові установи НАAН, $\epsilon$ наукові розробки, ефективність яких характеризується виходом захищених об’єктів інтелектуальної власності та впровадженими на їхній основі інноваційними проектами $[9 ; 10]$.

Опираючись на Звіт про діяльність Національної академії аграрних наук України за 2016-2020 рр., представимо інформацію щодо створення об'єктів права інтелектуальної власності (табл. 1).

За даними табл. 1 відмітимо, що за весь період було подано 1872 заявки на об'єкти інтелектуальної власності, в той час, як у цей же період ними було отримано 2245 охоронних документів [9]. 
Таблиця 1

\section{Створення об'єктів права інтелектуальної власності} у 2016-2020 pp.

\begin{tabular}{|c|c|c|c|c|c|c|}
\hline Роки & 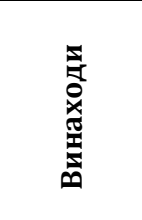 & 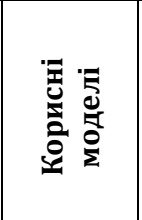 & 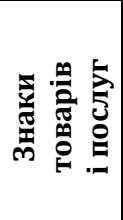 & 产 & 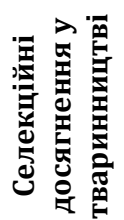 & 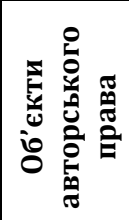 \\
\hline 2016 & $42 / 25^{*}$ & $107 / 188$ & $4 / 7$ & $123 / 118$ & $-/ 1$ & $27 / 39$ \\
\hline 2017 & $42 / 24$ & $186 / 192$ & $6 / 4$ & $161 / 199$ & $-1-$ & $37 / 57$ \\
\hline 2018 & $29 / 28$ & 209/184 & $8 / 4$ & $186 / 348$ & $-1-$ & $32 / 27$ \\
\hline 2019 & $22 / 32$ & $128 / 172$ & $12 / 5$ & $109 / 194$ & $-/-$ & $38 / 27$ \\
\hline 2020 & $26 / 24$ & $121 / 129$ & $2 / 2$ & $174 / 184$ & $-/ 3$ & $41 / 28$ \\
\hline $\begin{array}{l}\text { Усього по } \\
\text { НААНУ } \\
2016-2020 \text { pp. }\end{array}$ & $161 / 133$ & $751 / 865$ & $32 / 22$ & $753 / 1043$ & $-/ 4$ & $175 / 178$ \\
\hline
\end{tabular}

*Примітка: перед навскісною - подано заявок на отримання охоронних документів, за навскісною - отримано охоронних документів. Джерело: [9]

Дослідженнями доведено, що навіть при значній кількості запатентованих об'єктів інтелектуальної власності та їх успішного впровадження у виробництво, вартість таких об'єктів на балансах наукових установ у складі нематеріальних активів зовсім відсутня. Це пояснюється відсутністю нормативно-правових норм, які б регулювали порядок оцінки інтелектуальних активів в бюджетних установах [19].

Модель розвитку аграрного сектора економіки передбачає створення наукоємного середовища на ринкових засадах, яке спроможне забезпечити наукову розробку, освоєння прогресивних, стратегічно конкурентоспроможних технологій, впровадження їх у наукоємне виробництво та реалізацію якісної наукоємної продукції на товарно-споживчому ринку. Основою наукоємного ринку інновацій держави $є$ ії̈ науково-технічна сфера - головний продуцент наукового продукту, який реалізується на ринку у вигляді інновацій. Якщо вважати науку однією із галузей економіки, то можна стверджувати, що від економічного стану та динаміки її розвитку залежить інноваційний потенціал усієї економіки [4; 16; 18; 20]. До практичного вирішення завдань діяльності у сфері наукового 
забезпечення інноваційного розвитку сільського господарства в Донецькому регіоні функціонує Донецька державна сільськогосподарська дослідна станція НААН України. Пріоритетними напрямами інноваційної діяльності ДДСДС НААН є: селекція на насінництво сільськогосподарських культур; удосконалення й розробка нових систем землеробства, збереження і підвищення родючості грунтів; розробка та впровадження ресурсозберігаючих, екологічно безпечних технологій у рослинництві та тваринництві; виробництво та реалізація насіння високих репродукцій; апробація завершених розробок та їх адаптація до грунтово-кліматичних умов регіону; науково-консультаційний супровід впроваджених розробок [10].

Протягом 2021 р. науковцями Станції виконувались дослідження за 14 завданнями ПНД НААН, 3 яких 6 фундаментальних та 8 прикладних. Результати досліджень установи спрямовані на розробку інноваційних технологій із рослинництва й тваринництва, створення сортів зернових і кормових культур, розроблення науково-організаційних підходів та ринково-орієнтованого інструментарію випробовування, експериментального виробництва та консалтингового супроводу трансферу інноваційних технологій і продукції в агропромисловому комплексі регіону [10].

У 2020 році науковцями створено «Інноваційний портфель НДУ Донецького регіонального центру НААН». Вихідною базою для його створення були результати новітніх розробок наукових установ Донецького регіонального центру НАAН (Донецька державна сільськогосподарська дослідна станція НААН, Бахмутська дослідна станція розсадництва Інституту садівництва НААН та Донецький відділ родючості ґрунтів ННЦ ІГА НААН) за останні п'ять років [10].

Науковцями установи створено «Аналітично-інформаційний банк замовлень інноваційної продукції». Вихідною базою для побудови банку замовлень інновацій стали результати анкетного опитування сільськогосподарських товаровиробників в Донецькій області. Для участі в опитуванні було задіяно 175 сільськогосподарських товаровиробників, 3 них: 3 - агрохолдингу, 85 - агрофірм, 87 - фермерських господарств. 3 метою виявлення та вивчення пріоритетних напрямків впровадження інновацій у виробництво було поділено та структуровано замовлення таким чином, щоб було наочно видно потреби агрохолдингів, агрофірм та фермерських господарств в залежності від напрямку та галузі (рослинництво, землеробство, тваринництво) [10]. Найбільш пріоритетні замовлення інноваційної продукції серед агроформувань та фермерських господарств представлені графічно на рис. 3. 
У результаті опитування представників сільськогосподарських агроформувань було виявлено, що незважаючи на нестабільність інноваційної активності, товаровиробники намагаються інтегрувати передові науково-технічні розробки й адаптувати їх у власне виробництво. Свідченням цього $€$ новітні технології рослинництва, тваринництва та енергозберігаючі системи землеробства, які впроваджуються у виробничу діяльність.

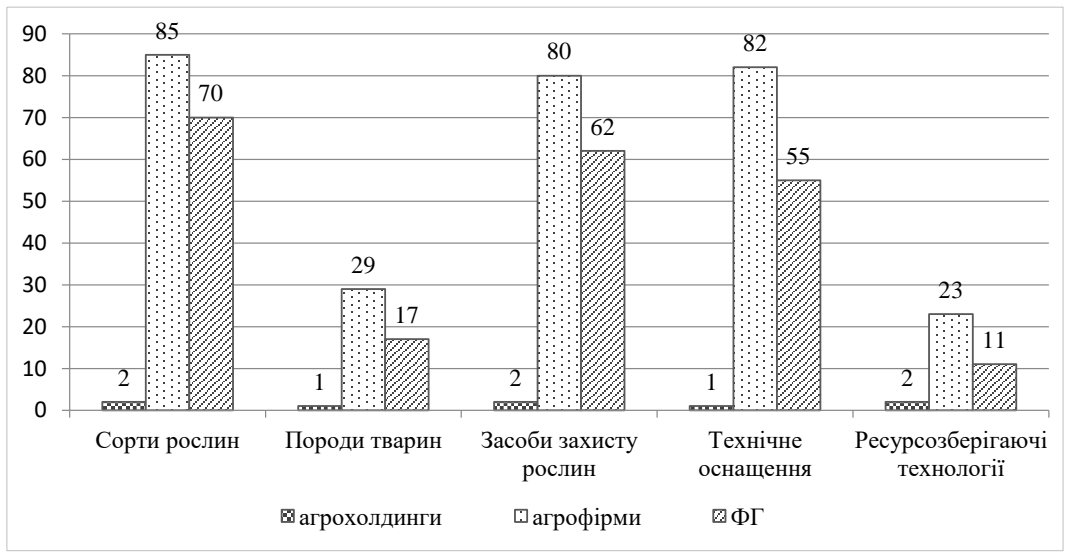

Рис. 3. Пріоритетні замовлення інноваційної продукції товаровиробників, 2020 р.

Джерело: складено автором за результатами опитування

Крім виявлення пріоритетних інноваційних розробок, в яких зацікавлені товаровиробники, особливої уваги потребує питання виявлення позитивних та негативних наслідків впровадження передових агроінноваційних технологій. Тому науковцями були проаналізовані можливості використання, переваги тієї чи іншої інноваційної продукції, а також виявленні проблеми адаптації та впровадження інновацій у виробництво в нинішніх економічних умовах.

Слід відмітити, що опитувані сільськогосподарські підприємства фінансують інноваційну діяльність виключно власними коштами, в окремих випадках залучають кошти державного бюджету (2 \%) та кредити (5\%). Основну частку коштів підприємства спрямовують на придбання машин, обладнання, установок (67\%) та оборотних засобів (насіння, добрив, засобів захисту рослин) (28 \%). 
В результаті проведеного дослідження, науковцями Станції встановлено, що для забезпечення стабільного розвитку сільського господарства, зміцнення економічної та технологічної безпеки галузі необхідне впровадження новітніх прогресивних технологій. Використання інновацій та техніко-технологічних розробок в аграрній галузі дасть змогу підвищити результативність ії діяльності. За рахунок інтенсивних технологій ведення вітчизняного сільськогосподарського виробництва можна досягти збільшення виробництва валової продукції, покращити ії якість, скоротити витрати ресурсів, що, в свою чергу, сприятиме підвищенню ефективності та прибутковості агровиробництва.

Аналіз стану розвитку агроформувань, використання ресурсного потенціалу, їх виробничо-господарської діяльності засвідчує, що з реформуванням АПК, появою господарств приватної власності значно погіршилась культура землеробства, знижується родючість грунтів, бо значно зменшилась кількість висококваліфікованих спеціалістів на селі, до керівництва сільгосппідприємствами прийшло багато людей без відповідної освіти. Самотужки оволодівати секретами агротехніки важко, тому особливо проявилась потреба в наукових рекомендаціях і розповсюдженні передового досвіду. Це потребує здійснення наукового супроводження інноваційних проектів, проведення постійно діючих тренінгів та тимчасових курсів навчання фахівців системи АПК, створення інформаційноконсультаційної мережі в області [8; 23].

У 2020 році проведено наукові дослідження, що дозволили систематизувати науково-технічні розробки Донецького регіонального центру, які $\epsilon$ комерційно цінними для освоєння в умовах Донецької області. Сформований банк науково-технічних розробок, які мають комерційну цінність і рекомендовані для освоєння в умовах Донецької області. розробок вміщує сорти ячменю ярого і пшениці озимої нашої селекції та новітні елементи технологій вирощування ярих культур. Впровадження розробок дозволило отримати економічний ефект у розмірі 2593,5 тис. грн/рік [10].

Маркетингові дослідження виявили, що з найбільш затребуваних інновацій $є$ сорти рослин та інтенсивні технології їх вирощування, $50 \%$ респондентів впроваджували у своєму господарстві нову високотехнологічну техніку. $37 \%$ товаровиробників виявили зацікавленість до розширення площ посівів та закупівлі насіннєвого матеріалу сортів донецької селекції, 72 \% - до консультування 3 питань технологій вирощування сільськогосподарських культур. 
Застосування науково-технічних розробок при виробництві основних видів продукції здійснюється у $56 \%$ господарств, $36 \%$ виробників застосовують окремі елементи інноваційних розробок і лише четверта частина господарств основою своєї діяльності вважає впровадження інновацій.

У 2020 році проводилося випробування 17 наукових розробок, в т. ч. в галузі землеробства - 1, рослинництва - 14, зоотехнії - 2 . Впроваджувалося 28 розробок в галузях агропромислового виробництва в 23 агроформуваннях регіонів, укладено 47 договорів (з них 42 - ліцензійних, 5 - на наукове забезпечення) на суму 3711,2 тис. грн [10].

\section{2. Впровадження та виробнича перевірка закінчених наукових розробок}

Впровадження ефективних заходів щодо розвитку аграрного сектору залежить від чіткої ідентифікації причин, які заважають цьому розвитку, зокрема активізації інноваційної діяльності сільськогосподарських підприємств та наукових установ. Науковцями були проаналізовані результати опитування товаровиробників та з'ясовані основні причини недостатнього впровадження інновацій у виробництво. Ці чинники згруповані за відповідними групами та представлені в табл. 2.

Таблиця 2

\section{Чинники, що перешкоджають здійсненню інновацій}

\begin{tabular}{|l|l|}
\hline \multicolumn{1}{|c|}{ Групи чинників } & \multicolumn{1}{|c|}{ Окремі чинники } \\
\hline Цінові чинники & $\begin{array}{l}\text { Відсутність коштів для фінансування } \\
\text { інноваційної діяльності }\end{array}$ \\
\hline Інформаційні чинники & Відсутність кваліфікованого персоналу \\
\cline { 2 - 2 } & $\begin{array}{l}\text { Відсутність інформації на ринку про } \\
\text { інноваційні продукти }\end{array}$ \\
\hline Ринкові чинники & $\begin{array}{l}\text { Відсутність попиту на інноваційні } \\
\text { технології, інноваційні продукти }\end{array}$ \\
\hline
\end{tabular}

Джерело: складено автором

Наукові установи аграрної сфери здійснюють своєчасне i достовірне інформаційне забезпечення виробничих і управлінських структур; надають консультаційні послуги; накопичують банки даних і знань за результатами завершених науково-дослідних робіт; організовують виробничі перевірки та експертні оцінки нових 
технологій і технологічних прийомів в грунтово-кліматичних умовах регіону; організовують показове впровадження (демонстраційні полігони, ферми, виставки, семінари); забезпечують консультативнонавчальне обслуговування виробників сільськогосподарської продукції; налагоджують виробництво насіння високих репродукцій та посадкового матеріалу високоврожайних сортів та гібридів сільськогосподарських культур.

Особлива увага наукових установ спрямована на розповсюдження науково-технічної, кон'юнктурно-економічної та патентної інформації, пропаганду науки та передового досвіду серед суб'єктів господарської діяльності через проведення обласних та районних семінарів, виставок, екскурсій на дослідних посівах, демонстраційних науково-технологічних полігонах в дослідних і базових господарствах. 3 цією метою у 2020 проведено 631 конференцію, семінар та нараду, 248 - виставок-ярмарок, 74 - дні поля, 226 круглих столів, надано 32539 консультацій, проведено навчання 15844 фахівців АПК, видано 2249 рекомендацій та інформаційних листків, здійснено 120 виступів по радіо та 134 на телебаченні. Протягом звітного періоду було забезпечено функціонування понад 200 демонстраційних полігонів та понад 20 модельних ферм [9, с. 597]. Налагоджено систему бізнес-пропозицій високоякісного насіннєвого матеріалу сільськогосподарських культур виробництва НААН та її мережі [9].

Слід зауважити, що наукова розробка стає інновацією, якщо вона рекомендована до масового впровадження у виробництво. Проте і в цьому разі вона має пройти стадію підготовки до такого освоєння іiї у виробництві, що сприятиме найповнішому використанню потенційних можливостей інновації. Відповідальність за ії створення зазвичай покладається на наукову установу. Про ефективність функціонування свідчить кількість і якість нових сортів рослин і їх освоєння у виробництві.

Впровадження результатів досліджень сприяє мобілізації інноваційного потенціалу наукових установ НААН України на проривних напрямах розвитку агропромислового комплексу, створенню конкурентоспроможної підприємницької системи трансферу інновацій із інвестиційним забезпеченням та інтеграційним супроводом, розвитку державно-приватного партнерства в системі аграрної науки шляхом реалізації самоокупних бізнес-проектів інноваційно-інвестиційного розвитку пріоритетних об'єктів АПК з дольовою участю держави, приватного капіталу та об’єктів прав на 
науково-технічну продукцію, залученню сучасних технологій та капіталу до участі в інвестиційному розвитку інноваційної інфраструктури аграрної науки, підвищенню конкурентоспроможності наукових установ на наукоємному аграрному ринку [2; 7].

Тому одним з головних напрямів діяльності наукових установ мережі НААН $\epsilon$ трансфер технологій в АПВ, формування і реалізація інноваційних проектів, здійснення наукового супроводу; проведення маркетингових досліджень 3 метою визначення попиту суб'єктів аграрного сектору на наукові розробки, моніторинг ринку технологій в АПВ. У рамках виконання завдань науковими установами проводяться маркетингові дослідження та аналізується попит на наукові розробки, доведені до рівня інновацій, вивчається ринкова ситуація в аграрному виробництві, аналізуються вже розроблені інноваційно-інвестиційні проекти та формуються нові, розробляються науково-технологічні програми розвитку галузей агропромислового виробництва та здійснюється їх впровадження у галузях рослинництва, землеробства, тваринництва, ветеринарної медицини в агроформуваннях різних форм власності.

Традиційна схема завершення науково-дослідних робіт передбачає передачу науково-технічних розробок науковими установами для апробації та впровадження у виробництво [7]. Випробуванню підлягають завершені науково-дослідні роботи, результати яких визнані науково-прикладними і потребують додаткової адаптації до регіональних умов. В 2019 році установами НААН України проводилась апробація наукових розробок, дані якої представлені на рис. 4.

Використання сортових рослинних ресурсів $€$ однією з найважливіших ланок сільського господарства - основою економічного й соціального розвитку держави. Від ефективності функціонування галузі селекції та насінництва зернових культур залежить рівень та якість забезпечення сільськогосподарських підприємств посівним матеріалом конкурентоспроможних сортів для здійснення сортозаміни та сортооновлення, що є важливою та невід'ємною складовою процесу зерновиробництва. На сьогодні сорт $є$ продуктом інноваційної діяльності, об'єктом інтелектуальної власності та нематеріальним активом, який значною мірою формує інтелектуальний та статутний капітал підприємств агропромислового комплексу. 


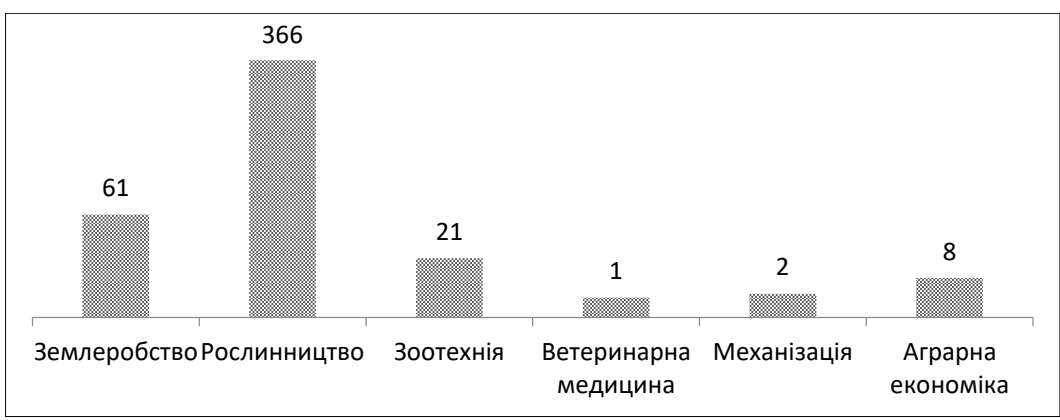

Рис. 4. Апробація наукових розробок установами НААН Джерело: складено автором за [9] y 2020 p.

Статистичні дані засвідчують низьку активність вітчизняних підприємств у сфері фінансування селекційної діяльності. У 2018 році створено 221 од. науково-технічної продукції в сфері селекційної діяльності (1,17 \% від загального обсягу створеної НТП), з них 207 од. створено за рахунок коштів загального фонду [11]. Такі дані свідчать про недостатню зацікавленість вітчизняних підприємств до вдосконалення посівного матеріалу, невпевненість селекціонерів у захисті свої прав на ОПІВ через низку негативних факторів.

Щорічно сортовий фонд сільськогосподарських культур поповнюється новими, більш ефективними сортами і гібридами. За даними Мінагрополітики України, в 2016 р. зареєстровано 9060 сортів рослин, придатних для поширення, з них найбільша кількість припадає на кукурудзу - 2297 сортів, соняшник 1286 сортів, пшеницю - 392 сортів [11; 13; 19; 22].

На думку вчених та фахівців, основними проблемами у сфері вітчизняної селекції в рослинництві є: відсутність можливості отримання матеріальної винагороди (роялті) вітчизняними селекціонерами за результатами практичного використання створеної ними продукції через недосконалість чинного законодавства у сфері використання інтелектуальної власності; відсутність державної підтримки сортів високих репродукцій та їхнього впровадження; відсутність стратегії ресурсного забезпечення селекційної діяльності; незахищеність українських патентів на фоні відсутності коштів для реєстрації таких патентів за кордоном; низька культура землеробства, що знецінює досягнення вітчизняних селекціонерів. Також негативною ситуацією для вітчизняного селекціонера $\epsilon$ орієнто- 
ваність сільськогосподарського товаровиробника на імпортне насіння. Ця ситуація суттєво погіршує конкурентні позиції вітчизняних селекційних центрів [19].

У системі НААН інноваційне насінництво ведеться у 46 наукових установах, 135 дослідних господарствах, по 550 сортах і гібридах 87 сільськогосподарських культур. Щорічно виробляється понад 60,0 тис. тонн базового насіння, 5,0 тис. тонн насіння первинних ланок, 1,1 тис. тонн батьківських форм гібридів кукурудзи, соняшнику, цукрових буряків, сорго, 70-80 т насіння овочевих i понад 100 т баштанних культур, 20,0 тис. тонн елітного насіння картоплі, 1,5 млн шт. саджанців плодових культур, 1,5 млн шт. саджанців винограду, а також насіння й саджанців інших культур. Насінницькі посіви мають займати в сівозміні не більше як одне-два поля (10-20\%). Крім того, більшість насінницьких посівів вимагає просторової ізоляції 0,8-3 км, що потребує їх розміщення серед полів інших культур [9].

Наукові установи аграрної сфери постійно працюють над удосконаленням сортових ресурсів, займаючись селекцією високопродуктивних, посухостійких сортів озимої пшениці та ячменю ярого. Більш сучасний, високопродуктивний сорт забезпечує не тільки зростання врожайності, якості, стійкості посівів до стресових факторів середовища, а й сприяє кращому використанню природних і антропогенних ресурсів, в тому числі потенціалу родючості грунту, внесення добрив, засобів захисту.

Впровадження науково-обгрунтованої структури посівних площ, сівозмін для господарств різної спеціалізації забезпечують стабільне виробництво зерна та кормів, комплекс заходів щодо підвищення стійкості і родючості грунтів, ефективного використання добрив. Наприклад, в Донецькому регіоні значним успіхом у виробників зернової продукції користуються сорти озимої пшениці Донецька 48, Білосніжка, Попелюшка, Богиня, Олексіївка, Краплина, Перемога, Ігриста, Юзовська, Диво донецьке; сорти ярого ячменю Донецький 12, Донецький 14, Донецький 15, Партнер, Східний, Степовик, Аверс, Щедрик, Сталий, Резерв, Реприз, Бравий. Нові сорти пшениці озимої Перемога, Ігриста, Юзовська і Диво донецьке ввійшли до Реєстру сортів у 2018 році та вже гідно оцінені агроформуваннями за високі господарські характеристики, бо вищезазначені сорти пшениці належать до цінних сортів та $€$ сортами інтенсивного типу універсального використання на високих і середніх агрофонах. За роки державного 
сортовипробування середня урожайність становила 5,3-7,1 т/га. Зерно має високий вміст білка (13,3-14,0\%) та клейковини (27,1-29,2\%), об'єм хліба з 100 г борошна складає 980-1000 см³. На державне сортовипробування передано сорт пшениці м'якої озимої Алмаз із заявленим показником урожайності 7,3 т/га, вмістом білка - 14,2 \%, об'ємом хліба з 100 г борошна - 1010 см$^{3}$ [10].

Національна академія аграрних наук України разом з потужними селекційними центрами може запропонувати сільськогосподарському виробництву широкий спектр сортів рослин і гібридів, та рекомендувати відповідну технологію їх вирощування. НААН щорічно формує та випускає «Каталог кращих інноваційних розробок», які рекомендовані для впровадження в агропромислове виробництво. В 2019 році до нього увійшли 300 розробок 52 науково-дослідних установ. Окрім того в наукових установах мережі НААН відпрацьовано ряд пілотних проектів із виробництва високорентабельних нішевих культур, які здатні надати новий імпульс розвитку вітчизняного АПК. Це, зокрема, проекти: промислового виробництва на основі біоадаптивних методів в умовах відкритого грунту; часнику - на основі високопродуктивних сортів; екологічно-чистої гречки з підвищеними адаптивними властивостями; горіха грецького - за інтенсивними технологіями; гірчиці - на основі органічних методів землеробства; біомаси для виробництва біопалива - на основі швидкоростучих фітоенергетичних ресурсів.

В табл. 3 наведено кількість сортів рослин, створених науковими селекційними центрами НАAН, які передано на державне сортовипробування та які вже занесено до Державного реєстру сортів рослин.

Відзначимо, що більшість виведених сортів і гібридів вітчизняних сільськогосподарських культур за продуктивністю й показниками $є$ конкурентоспроможними щодо зарубіжних сортів. Нині увагу селекціонерів спрямовано на підвищення зимостійкості та посухостійкості зернових культур, що в умовах континентального клімату України має виняткове значення.

Відмітимо, що належна правова охорона селекційних досягнень $\epsilon$ необхідною умовою для запобігання можливого порушення прав селекціонерів та інститутів-оригінаторів сортів рослин та порід тварин. Становлення системи охорони селекційних досягнень створює ринковий механізм, яким здійснюється законне обмеження використання (виключне право) об’єктів інтелектуальної власності 
третіми особами в комерційних цілях на визначений законом період та території. Така норма забезпечує підвищення економічної мотивації, сприяє формуванню нових ресурсів для подальших інновацій та відшкодуванню капіталовкладень за рахунок одержання прибутків на ринку. Ефективне використання переваг системи охорони об'єктів інтелектуальної власності дає змогу науковій установі та іншим підприємствам отримувати дохід від свого творчого потенціалу та творчої діяльності, що допомагає фінансувати у подальшому створювані інновації.

Таблиця 3

Кількість сортів рослин, створених науковими селекційними центрами НААН в 2016-2020 pp.

\begin{tabular}{|c|c|c|c|c|}
\hline \multirow[t]{2}{*}{ Група культур } & \multicolumn{2}{|c|}{$\begin{array}{c}\text { Передано на } \\
\text { державне } \\
\text { сортовипро- } \\
\text { бування сортів } \\
\text { (гібридів) }\end{array}$} & \multicolumn{2}{|c|}{$\begin{array}{c}\text { Занесено нових } \\
\text { сортів і гібридів до } \\
\text { Державного реєстру } \\
\text { сортів рослин, } \\
\text { приданих для } \\
\text { поширення в Україні }\end{array}$} \\
\hline & $\begin{array}{l}\text { y } 2016- \\
2020 \text { pp. }\end{array}$ & $\begin{array}{c}\text { у т. ч. } \\
\text { y } 2020 \text { p. }\end{array}$ & $\begin{array}{l}\text { y } 2016- \\
2020 \text { pp. }\end{array}$ & $\begin{array}{c}\text { у т. ч. } \\
\text { y } 2020 \text { p. }\end{array}$ \\
\hline Озимі зернові & 169 & 61 & 82 & 23 \\
\hline Ярі зернові & 262 & 103 & 246 & 56 \\
\hline Круп’яні & 11 & 3 & 13 & 2 \\
\hline Зернобобові & 30 & 9 & 28 & 4 \\
\hline Олійні & 82 & 29 & 115 & 10 \\
\hline Кормові & 35 & 13 & 56 & 10 \\
\hline Прядивні & 9 & 3 & 7 & 0 \\
\hline $\begin{array}{l}\text { Буряки цукрові / } \\
\text { кормові }\end{array}$ & 9 & 2 & 11 & 0 \\
\hline Картопля & 19 & 5 & 21 & 4 \\
\hline Овочеві & 73 & 23 & 62 & 13 \\
\hline Баштані & 6 & 5 & 7 & 1 \\
\hline $\begin{array}{l}\text { Ефіроолійні та } \\
\text { лікарські }\end{array}$ & 13 & 1 & 23 & 5 \\
\hline Плодово-ягідні & 47 & 9 & 50 & 11 \\
\hline Виноград & 7 & 0 & 5 & 5 \\
\hline Квітково-декоративні & 35 & 0 & 16 & 1 \\
\hline Усього По НААН & 807 & 266 & 742 & 145 \\
\hline
\end{tabular}

Джерело: сформовано за [9] 
Для покращення стану селекційної галузі та активізації зацікавленості селекціонерів та селекційних центрів потрібно вжити наступні заходи:

- забезпечити сільськогосподарських товаровиробників високоякісним насінням та посилити контрольну функцію 3 боку держави в усіх ланках насінництва;

- вжити необхідних заходів щодо впровадження нових сортів і гібридів сільськогосподарських культур, порід тварин в діяльність агроформувань $з$ метою збільшення валового обсягу виробництва продукції, а також збільшення показників експорту;

- забезпечити науково-дослідні установи необхідним фінансуванням на проведення наукових досліджень у галузі селекції, оновити їх матеріально-технічну базу;

- посилити державний контроль за порушенням прав суб'єктів селекційної діяльності, підвищити відповідальність за порушення майнових прав на селекційні досягнення;

- створити центри трансферу технологій, які виступатимуть посередником між науковими установами та бізнесом, що створить умови для більш ефективної селекційної діяльності за рахунок залучення інвестицій з підприємницького сектору, а також може забезпечити ефективну комерціалізацію наукових розробок у діяльність підприємств.

Випробування, впровадження та подальше широке поширення наукових розробок стають ключовими факторами зростання виробництва й зайнятості в сільському господарстві. Саме тут криються найбільш суттєві резерви поліпшення якості продукції, економії трудових і матеріальних витрат, зростання продуктивності праці, вдосконалення організації виробництва і підвищення його ефективності. Результати впровадження наукоємної продукції в діяльність сільськогосподарських підприємств у Донецькому регіоні представлено в табл. 4, що дозволить визначити пріоритетні напрямки та механізм впровадження i використання інновацій на регіональному ринку.

Сприйнятливість сільськогосподарських виробників до нових ідей, впровадження у найкоротші терміни інновацій забезпечать агроформуванням конкурентні переваги як на внутрішньому так i на зовнішньому ринках. В табл. 5 наведено інформацію щодо кількості агроформувань, в яких здійснювалось впровадження інновацій селекційними центрами НААН. 


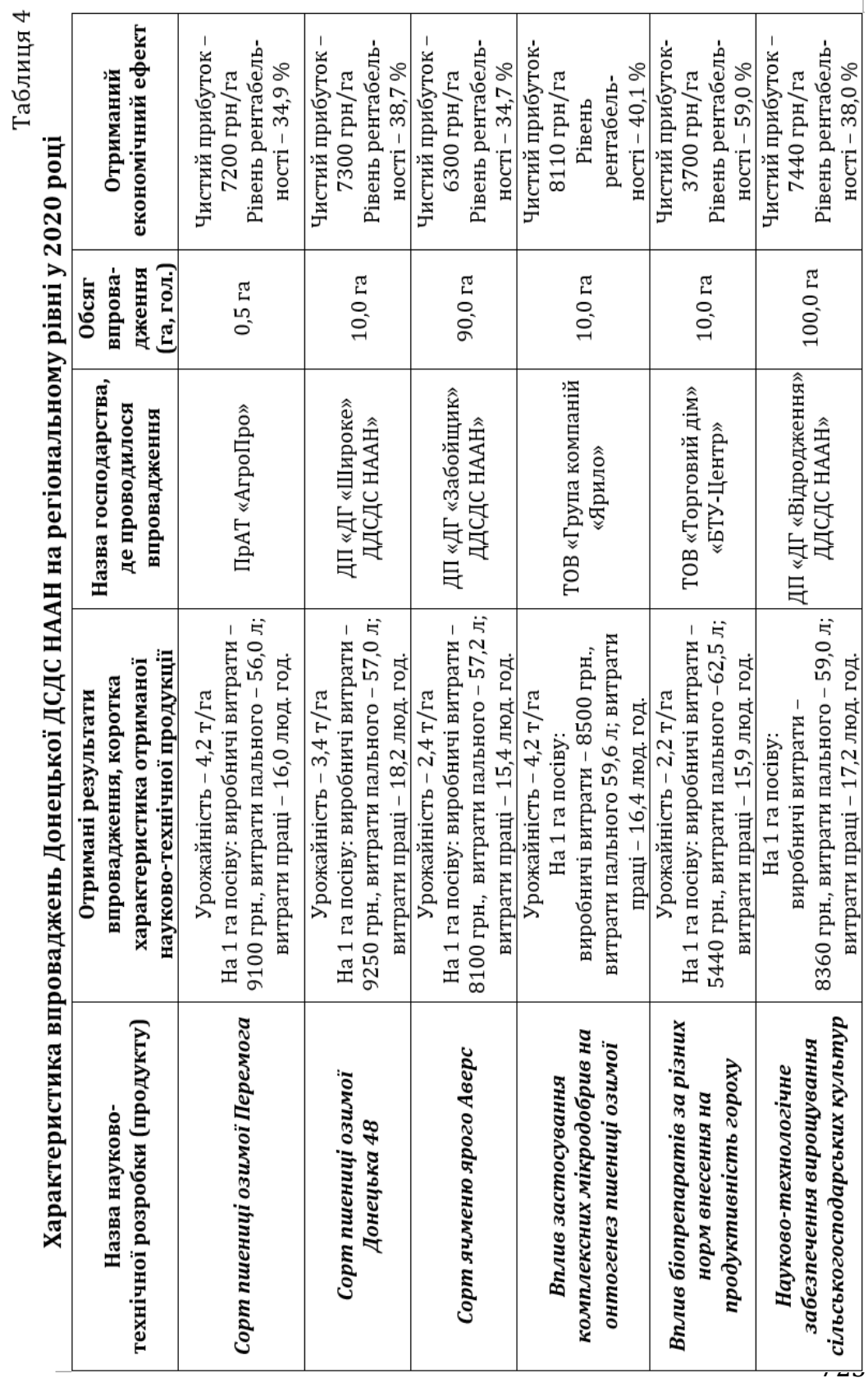


Таблиця 5

Впровадження інновацій у діяльність агроформувань селекційними центрами НААН України, 2020 р.

\begin{tabular}{|c|c|c|c|}
\hline \multirow[b]{2}{*}{$\begin{array}{c}\text { Співвиконавці } \\
\text { ПНД НААН } \\
\text { «Інноваційний } \\
\text { розвиток» }\end{array}$} & \multicolumn{2}{|c|}{ Кількість } & \multirow[b]{2}{*}{$\begin{array}{c}\text { Залучено } \\
\text { коштів до } \\
\text { спеціального } \\
\text { фонду, } \\
\text { тис. грн. }\end{array}$} \\
\hline & $\begin{array}{c}\text { агроформувань, } \\
\text { в яких } \\
\text { здійснювалось } \\
\text { впровадження } \\
\text { інновацій } \\
\end{array}$ & $\begin{array}{c}\text { укладання } \\
\text { договорів }\end{array}$ & \\
\hline $\begin{array}{l}\text { Наукові установи } \\
\text { мережі НААН }\end{array}$ & 707 & 752 & 33884,5 \\
\hline
\end{tabular}

Джерело: складено автором за [9]

У 2016-2020 pр. установами НААН проведено випробування 2405 закінчених наукових розробок, зокрема у галузях: землеробства - 277 , рослинництва - 1882, зоотехнії - 168, ветеринарної медицини - 1, харчової і переробної промисловості - 13, механізації - 12, аграрної економіки - 52. У 2020 році проведено випробування та адаптацію до грунтово-кліматичних умов 462 наукових розробок, зокрема у галузях: землеробства - 61, рослинництва - 366, зоотехнії - 21 , ветеринарної медицини - 1 , харчової і переробної промисловості - 2, механізації -3, аграрної економіки - 8 [9, с. 592].

\section{3. Ефективний механізм комерціалізації наукоємної продукції} та розробка шляхів активізації інноваційної діяльності

Позитивними наслідками ефективно організованої технології впровадження інновацій у діяльність сільськогосподарських підприємств є: розробка та впровадження інновацій, пов'язаних 3 новими сортами рослин, виведенням нових порід тварин, застосуванням нової техніки, підвищення урожайності культур; підвищення рентабельності діяльності підприємства; підвищення конкурентоспроможності сільськогосподарської продукції на внутрішньому та зовнішньому ринках. Так, наприклад, до біологічних інновацій входять: нові сорти та гібриди сільськогосподарських рослин, нові породи тварин, птиці, створення тварин та рослин, стійких до шкідників та хвороб. До технічних інновацій відносяться нові види техніки, обладнання, технології обробки сільськогосподарських культур, технології у тваринництві. До 
хімічних інновацій відносять нові добрива, їх системи, засоби захисту рослин.

Перехід мережі НААН на інноваційну модель розвитку за системою інноваційного провайдингу означає становлення Академії як ринково-адаптованої наукової організації, гармонізованої за відносинами як в інтелектуальній сфері, так і в бізнес-сфері. Це потребує створення і координації, функціонування та розвитку ринкової інноваційної інфраструктури Академії, інтегрованої з її науково-дослідною мережею [1; 4; 23].

Незважаючи на складну ситуацію в науковій галузі, результати наукових досліджень повинні вийти на ринок в якості інновацій. На сьогоднішній день проблема трансферу результатів наукових досліджень $є$ актуальною і перебуває в полі зору суспільства, уряду, бізнесу, самих науковців, оскільки саме вона визначає конкурентоздатність виробленої продукції, ефективність діяльності підприємств та рівень економічних перетворень. Велике значення під час комерціалізації інноваційної розробки мають пошук потенційного споживача та встановлення ціни на об'єкт трансферу $[8 ; 13 ; 14]$.

В аграрному секторі найбільш розповсюдженим методом трансферу є ліцензування об’єктів права інтелектуальної власності, зокрема сортів рослин. Наприклад, ДДСДС НААН у період 2015-2019 рр. було укладено 217 угод із господарствами Донецької, Запорізької, Дніпропетровської, Вінницької, Херсонської областей на використання прав на сорти рослин та на використання прав на корисні моделі.

Згідно чинного законодавства та вітчизняної практики передача права на використання об'єктів інтелектуальної власності оформляється ліцензійним договором і роялті $\epsilon$ найбільш розповсюдженим способом оплати за цими ліцензійними договорами. Згідно 3 положеннями Цивільного кодексу України істотною умовою за ліцензійним договором є визначення платежу. Як правило, при укладанні такого виду договору спрацьовує ринковий механізм все залежить від потенціалу, пластичності сорту, яку нішу він займатиме в сільському виробництві, наскільки буде затребуваний, а також наскільки прийнятний для споживача розмір винагороди поставить власник нового сорту рослин. Досить часто сорти рослин селекційні центри продають без використання ліцензійних договорів, що в цілому є однією з перешкод щодо прискорення 
процесів розповсюдження та залучення у виробництво високопродуктивних сортів сільськогосподарських культур.

Відмітимо, що для ліцензіара (наукової установи) головною метою є комерціалізувати інтелектуальний продукт за винагороду та розширити свій вплив на інших ринках із охопленням більшої кількості компаній на значній території, ніж це робилось би суб'єктом господарювання самостійно [25, с. 63]. Також перевагою ліцензування є те, що воно допомагає суб'єктам ліцензійної угоди отримати доступ до нових ринків, які для них раніше були недоступні. Ліцензіар, надавши ліцензіату виключні або невиключні права на об'єкт інтелектуальної власності, може захопити нову частину ринку, на яку він раніше не мав змоги потрапити та обслуговувати. Також на умовах ліцензування можна отримати доступ до створених брендів, освоєних технологій, що може надати покупцю ліцензії - ліцензіату економічні вигоди без значних капітальних інвестицій у власні дослідження та розробки. Такий інструмент вигідний для малих суб'єктів господарювання в зв'язку з відсутністю значних матеріальних, трудових та фінансових ресурсів для створення нового інноваційного продукту.

Проаналізувавши переваги ліцензування та широкий спектр можливостей, які він може надати обом сторонам ліцензійної угоди, виділимо основні прояви ризиків. Основний ризик процесу ліцензування полягає в тому, що ліцензіат, який впроваджує у виробництво запатентовану технологію та реалізує в подальшому продукцію за ліцензією, може стати прямим конкурентом ліцензіара. В такому випадку діяльність ліцензіата на ринку може привести до зменшення обсягів продажу продукції ліцензіаром. Така ситуація склалась у вітчизняних науково-дослідних установах аграрної сфери. Селекційні центри на умовах невиключних ліцензій надають права на використання сортів рослин сільськогосподарським товаровиробникам на визначений строк та певну територію. Зазвичай, ліцензіатами виступають агрохолдинги та комерційні фірми зі значними капітальними інвестиціями, які мають сучасну матеріально-технічну базу для виробництва якісного насіннєвого матеріалу за ліцензією. Ліцензіати, маючи відповідне оснащення, на відміну від науково-дослідної установи при їі мінімальному бюджетному фінансуванні надають логістичні послуги, агрохімічні послуги, консультативну підтримку комплексу робіт від посіву до збирання врожаю. Таким чином, ліцензіат поширює свій вплив на значну територію та захоплює потенційних клієнтів селекційної 
установи - оригінатора насіння. 3 одного боку покупець ліцензії забезпечує ліцензіара грошовими надходженнями від надання прав на використання сортів рослин у вигляді паушальних платежів та роялті, але, з іншого боку, зменшує обсяги продажу добазового та базового насіння ліцензіаром третім особам [15; 24].

У діяльності наукових установ виявлена основна проблема, яка полягає в тому, що українським селекціонерам не вистачає коштів для проведення наукових досліджень. Частково, це може бути вирішено ефективним механізмом залучення роялті за надання права на використання сортів рослин. Тобто вітчизняні наукові установи будуть мати додаткові грошові надходження, що можуть виступати значним фінансовим джерелом для фінансування досліджень та розробок селекційних досягнень, і це буде значним стимулом для діяльності селекціонерів. Започаткувавши ефективний механізм залучення роялті, виплата винагороди за право виробництва елітного та репродукційного насіння й садивного матеріалу в повному обсязі дала б змогу селекціонерам та селекційним установам щороку одержувати до 3,0 млрд гривень.

Як показує досвід Європейського Союзу, в більшості європейських країн фермери, які засівають понад 20 га власним насінням, сплачують роялті в розмірі $50 \%$ від вартості вирощеного або реалізованого насіння. Розмір роялті лежить у певному діапазоні, але кожен власник патенту має право встановлювати його у відповідності зі своїми уявленнями. По зерновим культурам розмір роялті коливається між 8 і 17 євро за 100 кг насіння, по бобовим 8-12 євро за 100 кг насіння, а по картоплі - 4-9 євро за 100 кг посадкового матеріалу. Аналізуючи ставки роялті в наукових установах Національної академії аграрних наук, можна стверджувати, що вони теж формуються диференційно відповідно до культури, репродукції насіння. Наприклад, ставки роялті за ліцензійними договорами на використання озимої пшениці, ячменю ярого Донецької державної сільськогосподарської дослідної станції наступні: 7-9 \% супереліта, 5-7 \% еліта, 5-сертифіковане насіння [10].

Наразі в Україні об'єкти права інтелектуальної власності стали одним із активних індикаторів економічних відносин. Розвиток національної системи їі охорони створив передумови для використання результатів інтелектуальної діяльності у формі товару.

Практичне значення для розуміння всієї картини стосовно грошових надходжень у вигляді роялті та кількості укладених 
ліцензійних угод науковими установами Національної академії аграрних наук України набувають дані, наведені на рис. 5.

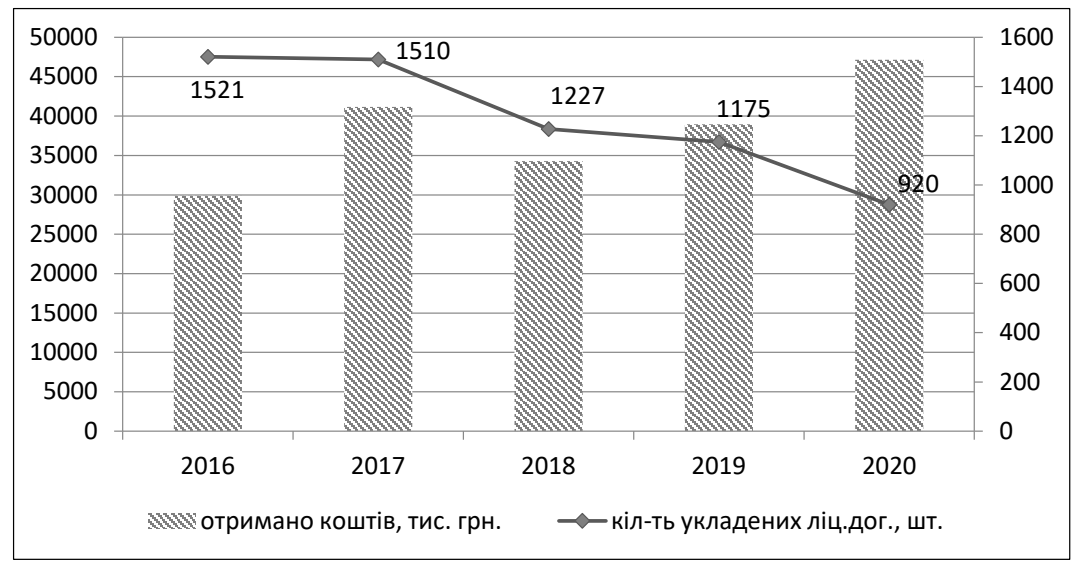

\section{Рис. 5. Результати комерціалізації наукової} та наукомісткої продукції у 2016-2020 рр. Джерело: сформовано автором за [9]

На нашу думку, чіткий та прозорий підхід сплати роялті суттєво міг би змінити відносини між селекціонерами й виробниками насіння для забезпечення справедливих фінансових розрахунків, надав би новий кардинальний поштовх для розвитку селекції. Але необхідно на першому етапі облік сортових посівів у господарствах усіх форм господарювання вести через систему обов'язкової звітності Державної служби статистики України, яку необхідно збирати щороку після закінчення посівної кампанії.

Таким чином, механізм залучення та контролю роялті - це не тільки справедлива винагорода авторам селекційних досягнень за довголітню та плідну працю, але і новий інструмент залучення в селекційну сферу грошових інвестицій, що також буде основою для стимулювання впровадження в сільське господарство кращих селекційних досягнень світової науки. В результаті дослідження доведено, що для ефективного механізму залучення роялті необхідна тісна взаємодія вчених-селекціонерів і сільськогосподарських товаровиробників. При цьому особливу значимість для реалізації впровадження механізму роялті відводиться державі, яка через певне відомство в сфері регулювання агропромислового 
комплексу країни визначає політику щодо розвитку та продуктивності сільськогосподарських культур.

Активізації інноваційної діяльності в сільському господарстві на етапах розробки, апробації та відтворення новацій сприятиме створення технопарків та інших інноваційних структур на регіональному рівні. Створення нових науково-технологічних структур технопаркового типу може стати важливим фактором розвитку інноваційної інфраструктури аграрної сфери [8, с. 166].

Сучасний технологічний парк науковцями розглядається як форма територіальної інтеграції науки, освіти й виробництва у вигляді об'єднання наукових організацій, навчальних закладів, виробничих підприємств або їх підрозділів з метою прискорення розробки і застосування науково-технічних і техніко-технологічних досягнень [5; 7; 12].

Реалізація технопаркової концепції інноваційного розвитку регіонів можлива тільки за умов скоординованої діяльності i співпраці науки, вищої школи, підприємств різних форм власності, державних та місцевих органів влади. Визначальна роль у розвитку технологічних парків належить державі, яка формує стратегію інноваційного розвитку та проводить політику заохочення інноваційної активності суб'єктів господарювання [7; 8; 12]. Як зазначають Кирилов Ю.Є., Грановська В.Г., створення системи агротехнопарків сприяє швидкій апробації передових технологій і вивченню економічної ефективності [12, с. 65].

Нині ключовою є проблема залучення інвестиційних ресурсів в інноваційний розвиток та їх раціонального використання, і від розв'язання цієї проблеми залежать можливості подальшого економічного розвитку аграрного виробництва. Інвестиційний дефіцит, зумовлений згортанням державної фінансової підтримки сільськогосподарських підприємств, відсутністю розвиненої фінансово-кредитної інфраструктури, зміною домінант державної аграрної політики, збільшенням цін на промислову та сільськогосподарську продукцію, високим рівнем зношення матеріальнотехнічної бази аграрного виробництва низькою інвестиційною привабливістю окремих сегментів аграрної сфери, - є фактично основною перешкодою для активізації інноваційного попиту товаровиробників [22, с. 69]. Економічні відносини між наукою та виробництвом недостатньо налагоджені, повільно впроваджуються у виробництво наукові розробки. Оновлення сільськогосподарського виробництва новими сортами, технікою, техно- 
логіями стримують такі фактори як низька платоспроможність сільськогосподарських товаровиробників і недостатня інформованість їх щодо новітніх досягнень вітчизняної сільськогосподарської науки [22, с. 69].

На основі виявлених вище тенденцій, які склалися 3 провадженням інноваційної діяльності вітчизняних наукових установ аграрної сфери запропоновано ряд напрямів активізації інноваційної діяльності:

- розвиток власного дослідницького потенціалу, виконання науково-дослідних робіт і випуск науково-інноваційної продукції;

- впровадження інноваційних технологій, власних розробок у виробництво;

- формування відповідного економічного механізму, що дасть змогу отримувати додаткові фінансові ресурси;

- підвищення рівня кваліфікації й самосвідомості кадрів наукових установ, підвищення корпоративної культури академій, наукових центрів, інститутів;

- проведення маркетингової роботи 3 метою розширення ринків збуту інноваційної продукції наукових установ та задоволення запитів споживачів;

- забезпечення та організація правової охорони інноваційних ідей;

- створення інтенсивних інформаційних потоків між учасниками інноваційного процесу;

- створення стійкого матеріального і морального стимулювання наукових співробітників - авторів розробок із метою підвищення ефективності інноваційної діяльності та конкурентоспроможності продукції;

- розширення практики створення технопарків, високотехнологічних бізнес-інкубаторів, інноваційних центрів, іншої інфраструктури інноваційної діяльності;

- запровадження комплексу податкових та інших пільг, які надаються виконавцям відповідних робіт.

Досліджуючи проблему інноваційного розвитку наукових установ, не можна проігнорувати пріоритетну роль держави в активізації інноваційної діяльності підприємств. Одним із ключових завдань державної політики України має стати формування системи інституціональних відносин між наукою, освітою та виробництвом, коли інновації стають основою прогресу, а потреби інноваційного розвитку вітчизняних підприємств, у свою чергу, 
багато в чому визначають і формують найважливіші напрями наукової діяльності. Саме тому для фінансового забезпечення інноваційного розвитку сектору економіки необхідно сконцентрувати капітал на пріоритетних напрямах розвитку, зокрема освіті, науці, прогресивних технологіях, підприємницькій активності на ринку наукоємної продукції.

\section{Висновки}

У результаті дослідження встановлено, що інноваційна діяльність виступає потужним каталізатором розвитку економіки, $\epsilon$ надійною гарантією високоефективного бізнесу. Виходячи 3 вищесказаного, здійснення інноваційної діяльності науковими установами дасть змогу підвищити рівень їхньої конкурентоспроможності, зміцнити позиції на міжнародному ринку та покращити ефективність виробничо-господарської діяльності загалом. Впровадження наукових розробок у діяльність агроформувань регіону надасть можливість розкрити потенціал малого та середнього бізнесу, збільшить податкові надходження до бюджетів, сприятиме покращенню якості продукції з використанням інноваційних технологій. При створенні дієвої системи, спрямованої на інноваційний розвиток сфери АПК, потрібна інтеграція бізнесових, державних, наукових структур, що здатна сформувати нові відносини між наукою, державою та бізнесом та стане дієвим інструментом забезпечення конкурентоспроможного розвитку аграрних підприємств на регіональному рівні.

Зв'язок науки з виробництвом здійснюється через трансфер розробок, що $є$ найскладнішою стадією у просуванні інновацій. Підтверджено, що успішно впроваджувати закінчені наукові розробки можна тільки тоді, коли його учасниками поряд із науковцями та виробничими суб'єктами є інвестиційні компанії, представники венчурного капіталу, провайдингові структури. Для цього доцільно створювати в аграрній науці тимчасові підрозділи для впровадження у виробництво наукових розробок. На регіональному рівні створення обласних аграрних науковоінноваційних фондів стимулюватиме розвиток інноваційних процесів в агропромисловому виробництві. Скорочення періоду просування наукової розробки на ринок $є$ важливим моментом інноваційної діяльності, тому на стадії перетворення науковотехнічної продукції в інноваційний продукт постає питання виміру її інноваційності. Створення механізму оцінки рівня інноваційності 
надало б можливість скорочувати період просування наукової розробки на ринок і розраховувати обсяг виробництва та реалізації інноваційних продуктів і (або) продукції чи послуг у грошовому вимірі, розмір якого визначає господарюючий об'єкт як інноваційне підприємство.

Активізація розвитку аграрної науки потребує створення ефективної системи прогнозування науки, формування пріоритетів i постійного планування науково-дослідних робіт. Визначення державою пріоритетним напрямом інноваційної діяльності технологічне оновлення й розвиток агропромислового комплексу та пріоритетним напрямом розвитку науки і техніки - раціональне природокористування передбачає розроблення Державної цільової науково-технічної програми розвитку пріоритетних видів інноваційних продуктів та інноваційної продукції аграрної науки, методично узгодженої із чинною системою державних прогнозів і програм соціально-економічного розвитку України. Одним із основних засобів державної підтримки наукової та науковотехнічної діяльності $\epsilon$ державне замовлення на розроблення інноваційної продукції через формування державних науковотехнічних програм із проведення наукових досліджень, створення та освоєння нових видів техніки і технологій. Поліпшенню інноваційної діяльності буде сприяти створення фонду закінчених наукових розробок.

\section{Список використаних джерел:}

1. Балян А. В. Роль і місце аграрної науки у забезпеченні продовольчої безпеки України. Проблеми ринку продовольчих ресурсів України : матеріали I наук.-практ. конф. (Ін-т прод. ресурсів НАAН, 10 квіт. 2013 р.). К. : ННЦ IAE, 2013. С. 3-7.

2. Вергунов В.А. Наукові основи інноваційного розвитку аграрної науки на регіональному рівні. Вісник аграрної науки. 2019. № 5 (794). C. 70-75.

3. Вініченко I.I. Інноваційна діяльність аграрних підприємств: стан та пріоритети. Бюлетень Міжнародного Нобелівського економічного форуму. 2012. № 1 (5). С. 44-48.

4. Володін С.А. Інноваційний розвиток аграрної науки. Київ : МАУП, 2006. $400 \mathrm{c.}$

5. Володін С.А. Теоретико-методологічні та організаційні засади інноваційного провайдингу на наукоємному аграрному ринку. Київ : 3АТ «Нічлава», 2007. 384 с. 
6. Гончаренко О.В. Інноваційний розвиток аграрних підприємств у контексті формування інформаційної економіки. Актуальні проблеми економіки. 2012. № 10 (136). С.103-109.

7. Гордієнко В.П. Інноваційний розвиток регіонів на основі технопаркової концепції. Економічний простір. 2011. № 46. С. 37-44.

8. Жидяк О.Р. Інноваційний розвиток підприємств аграрної сфери: регіональний аспект. Економіка: реалії часу. 2012. № 2 (3). C. $166-168$.

9. Звіт про діяльність Національної академії аграрних наук за 2016-2020 роки та 2020 рік / за ред. В.В. Адамчук, О.Є. Гузеватий, В.В. Кузьмінський. К. : ДВ «Аграрна наука» НААН, 2021. 763 с.

10. Інформаційний звіт про діяльність Донецької державної сільськогосподарської дослідної станції НААН України за 2020 рік / за ред. О.О. Вінюков, Н.А. Воленщук, О.Б. Бондарева. 2020. 71 с.

11. Інформаційний портал Державної служби статистики України. URL: http://www.ukrstat.gov.ua/

12. Кирилов Ю.Є., Грановська В.Г. Агротехнопарки - інноваційний напрям конкурентоспроможного розвитку підприємств аграрного сектору. Економіка АПК. 2017. № 6. С. 65-73.

13. Крачок Л.І. Новітні технології у сільському господарстві: проблеми і перспективи впровадження. Сталий розвиток економіки. 2013. № 3. С. 224-231.

14. Ляшенко О.М. Комерціалізація та трансфер технологій: категорії та методи інноваційної діяльності. URL: http:// masters.donntu.org/2013/iem/suhanov/library/ar2.pdf.

15. Ляшенко О.М. Комерціалізація та трансфер технологій: категорії та методи інноваційної діяльності. Інноваційна економіка. URL: http://masters.donntu.org/2013/iem/suhanov/library/ar2.pdf

16. Месель-Веселяк В. Я. Організаційно-економічні умови розвитку аграрного виробництва в Україні. Економіка АПК. 2010. № 9. С. 3-12.

17. Омельяненко Л.І., Мединська О.Я., Кузишин Н.С. Наукове забезпечення інноваційного розвитку аграрної сфери на регіональному рівні. Інноваційна економіка. 2016. № 7-8. С. 91-98.

18. Петров В.М. Інноваційні пріоритети технічної політики в АПК. Економіка АПК. 2005. № 7. С. 11.

19. Пічкур О. В. Правова охорона селекційних досягнень у рослинництві. К. : Авокадо, 2006. 804 с.

20. Саблук П. Т. Стратегічний напрям аграрних реформ - перехід на інноваційну модель розвитку. Вісник Академії економічних наук України. 2003. № 2 (4). С. 11-16. 
21. Смолінський В.Б. Проблеми державного регулювання інноваційної діяльності в аграрній сфері економіки. Науковий вісник НЛтУ України. 2011. Вип. 21(2). С. 286-290.

22. Спаський Г.В. Інновації в розвитку аграрних підприємств Закарпатської області. Вісник аграрної науки. 2017. С. 67-73.

23. Стратегічні напрями розвитку сільського господарства України на період до 2020 року / за ред. Ю. О. Лупенка, В. Я. МесельВеселяка. К. : ННЦ «ІАЕ», 2012. 182 с.

24. Тимчук В.М. Проблемні питання трансферу технологій в АПВ. Вісник аграрної науки. 2013. № 2. С. 23-25.

25. Трусевич В. Особливості ліцензування прав на об'єкти інтелектуальної власності. Економіка України. 2007. № 5. С. 60-67. 